\title{
Is Facebook A Planet of Lonely Individuals? : \\ A Review of Literature
}

\author{
Shelly Bhagat ${ }^{1}$
}

\section{ABSTRACT}

Social media is a new formed society for individuals to interact and connect with each other, despite of their caste, class, region, religion, and race, which eventually is focusing on the overall wellbeing of individuals surfing on social media regularly. Loneliness has a major influence on psychosocial problems, mental health, and physical well-being which is now focusing the individuals more who spends most of the time online. Many people on social media sites often present idealized versions of their lives, leading others to make upward social comparisons, which can lead to negative emotions. Social interactions on social media sites, specifically Facebook, may have a negative impact on face-to-face encounters for individuals who already have high levels of Loneliness and anxiety. In the present review, loneliness is introduced as an exemplar of social media deficits highlighting the social media website Facebook. Here a definition of loneliness is provided, as well as explanation of why it may pose a situation of concern for Facebook users.

Keywords: Loneliness, Facebook, Social media

As a social being, most of us feel the need for rewarding social contact and relationships. One common phenomenon of loneliness is that it is the feeling we get when our need for this type of contact is not met. People find themselves in a state where they actually don't find any companionship due to any reason. And in the, modern era of INTERNET, they search their needs online. Need to be in contact with someone, need to express their feelings, need to express their interest, need to socialize... yes, this "needs to socialize", they actually get fulfilled on Internet, the networking planet.

Loneliness is that subjective experience which can be related to but is not synonymous with social Isolation. It has been described as a sad subjective state resulting from dissatisfaction with one's social experiences (Youngblade, Berlin, and Beslky, 1999.p.136). There is however, a common general consensus among researchers about the inevitability of loneliness (Medora and Woodward, 1986). Loneliness is always seen as a painful experience, which is perhaps is an inevitable part of living (Russell, 1996), and is comprised of many unfulfilled needs of an individual (Weiss, 1973). Feelings of loneliness may be either persistent or short-lived (Peplau

\footnotetext{
${ }^{1}$ Research Scholar at Department of Psychology, Punjab University Chandigarh. (C) 2015 I S Bhagat; licensee IJIP. This is an Open Access Research distributed under the terms of the Creative Commons Attribution License (http://creativecommons.org/licenses/by/2.0), which permits unrestricted use, distribution, and reproduction in any Medium, provided the original work is properly cited.
} 
and Perlman, 1982). Many individuals get the social support in such tough phase of life when they suffer Loneliness, and many others found that support on Internet, which is provided to them by the so called Social Networking sites. These sites generate social relations among people who share similar interests, activities, backgrounds or real-life connection. The most popular and the one among several social networking sites connecting people at present is "Facebook". Launches in February, 2004, Facebook has 1.18 billion monthly active users as of June 2015. As per the latest data fetched by the website: topexensivelist.com (http://topexpensivelist.com/main-10-countries-with-the-highest-number-of-facebook-

users/2/), top 10 countries using maximum of this site are shown in the table below:

\begin{tabular}{|l|l|l|}
\hline S.NO. & COUNTRY & DESCRIPTION \\
\hline 1. & $\begin{array}{l}\text { United States } \\
\text { of America } \\
\text { (U.S.A) }\end{array}$ & $\begin{array}{l}\text { No. 1 in using facebook. 67\% of the } \\
\text { total 78\% users on internet are on } \\
\text { Facebook too. Total end users of } \\
\text { Facebook 160 million, and the age } \\
\text { ranges from 18-34 are the highest! }\end{array}$ \\
\hline 2. & India & $\begin{array}{l}\text { At no. 2 India takes up the position } \\
\text { with a total Facebook user of } \\
\text { approximately 62 million. Male } \\
\text { users are more dominant at this side. } \\
\text { The bigger chunk of the users is } \\
\text { above 18, so mostly young adults are } \\
\text { on this website. }\end{array}$ \\
\hline 3. & Brazil & $\begin{array}{l}\text { Ladies and Gentlemen both takes an } \\
\text { equal participation in the social } \\
\text { networking website, and the total no. } \\
\text { of users comes up to 68 million. }\end{array}$ \\
\hline 4. & Indonesia & $\begin{array}{l}\text { The population of the beautiful } \\
\text { archipelago of Indonesia seems to be } \\
\text { a bit addicted to facebook. 20\% of } \\
\text { the 22\% of people who use internet } \\
\text { here are on Facebook. Male } \\
\text { members dominate the website. }\end{array}$ \\
\hline 5. & Mexico & $\begin{array}{l}38 \text { million total users. Both genders } \\
\text { are balanced. }\end{array}$ \\
\hline 6. & Tnited & $\begin{array}{l}\text { About 53\% of the internet users are } \\
\text { on Facebook. From approximately } \\
33 \text { million users here, around 51\% } \\
\text { are the ladies. }\end{array}$ \\
\hline $\begin{array}{l}32 \text { million users sharing their lives } \\
\text { with each other on Facebook. } \\
\text { Gender based usage is equal. Young }\end{array}$ \\
\hline 7 Turkey
\end{tabular}




\begin{tabular}{|l|l|l|}
\hline & & $\begin{array}{l}\text { adults form the most of the users } \\
(18-35 \text { years old }) .\end{array}$ \\
\hline 8. & Philippines & $\begin{array}{l}\text { 29 million users, with Filipino ladies } \\
\text { take the lead when it comes to } \\
\text { Facebook usage. }\end{array}$ \\
\hline 9. & France & $\begin{array}{l}25 \text { million users dedicated to } \\
\text { Facebook. }\end{array}$ \\
\hline 10. & Germany & $\begin{array}{l}\text { Number reaches to 22 million of the } \\
\text { total users at present, and 65\%-70\% } \\
\text { users are in the age range of 18-44. }\end{array}$ \\
\hline
\end{tabular}

\section{HEALTH BENEFITS OF FACEBOOK:}

1. Fuel Self-Esteem:- People in general feel better about themselves after they updated their Facebook profiles. According to researchers, the very act of posting something about yourself regardless of what you write can actually boost your self-confidence because you control the image you present to your network of friends.

2. Strengthen friendship bonds:-This site helped many individuals to cement positive interaction among friends. Both private messages and wall posts allowed Facebook users to confide in their friends, surf down memory lane, and laugh out loud, promoting happy feelings.

3. Stamp out shyness and Loneliness:-Adults receiving messages from friends and consuming information from friends' news feeds gets boost in feelings of connectedness, especially in people with self-described "low social skills".

\section{HEALTH RISKS OF FACEBOOK:}

1. Psychological Disorders:-Individuals spending too much time on social media, leading them to turn to "substance abuse, unsafe sexual practices, or aggressive or self-destructive behaviors, stress, depression, the feeling of Loneliness and aloofness from their working environment."Satisfying social relationships are vital for good mental health, loneliness has been found to be inversely correlated to life satisfaction (Schumaker, Shea, Monfries, \& GrothMarnat, 1993; Schultz \& Moore, 1988).

2. Trigger Eating Disorders:-The more time people spent on social networking site, the more likely they were to develop eating disorders such as anorexia, bulimia, and extreme dieting. Exposure to online fashion and music content, are also associated with an increased risk for eating disorders. Hawkley \& Cacioppo (2007) in survey of over 2,500 OSU undergraduates (mean age $=19.1$ years), found that loneliness was associated with a slightly greater body and older (mean age, 46.3 years), the lonely group had a higher mean BMI and a greater promotion of overweight/obese individuals than the non-lonely group did (Lauder, Mummer, Jones, \& Caperchione, 2006).

3. Split up marriages:-Facebook can become reference in divorce petitions with the help of cyber crime reports. People do generally meet up with their past relationships on the networking sites which can generate the feelings backs and lead to cheating on their spouse. 
4. Addiction of Social Networking:-"for those post status updates, the reinforcements keep coming in the form of supportive comments and likes. And of course we know that behaviors that are consistently reinforced will be repeated, so it becomes hard for a person who has developed this habit to simple stop. Social media is delivering reinforcement every time a person logs on. It is presumably correct that quitting Facebook is much more difficult than giving up cigarettes or alcohol.

If an emotional change in one person spreads and cause a change in many, then we may be dramatically underestimating the effectiveness of efforts to improve mental and physical health. Smaller social networks and less frequent interactions with friends and family promote loneliness (Dykstra, van Tilburg, \& de Jong Gierveld, 2005; Pinquart \& Sörensen, 2003). Accordingly, situational factors that influence the availability of social opportunity have also been associated with loneliness. For example, geographic relocation predicts loneliness in first year university students (Shaver, Furman, \& Buhrmester, 1985).Overall, it appears that the exact effects of social media on our mental health and well-being remain to be seen. But one thing is certain; our use of social networking sites is unlikely to fade anytime soon.

\section{SUMMARY}

Thus, in summary, the social networking site Facebook has been demonstrated to be associated with number of psychosocial difficulties (e.g., low self self-esteem, low social competence, poorer quality social interactions), as well as mental health problems (e.g., anxiety, depression, loneliness, addiction), and physical health issues (e.g., poorer immune and cardiovascular functioning, sleep deficiencies, eating disorders). Moreover, the people who attach themselves to Facebook often end up creating differences between themselves and the real social environment, which gradually makes them lonely in their life. Spending too much time on Facebook for self satisfaction of sociability makes a person detached from their immediate live environment and makes them more prone to the environment which they have created for themselves on the social networking site "Facebook". Although many studies point to the negative impacts of social media on mental Health and well-being, some researchers say that could have the opposite effect. Social networking sites mainly Facebook, could be a useful tool in identifying individuals with mental health issues. Negative conditions such as "Facebook Depression" or Facebook-fueled divorces bear the brunt of the media blitz, but much of the body of research actually points to positive perks from Facebook use. How all those "likes”, "pokes”, and status updates are really affecting someone and their family's well-being, and how an individual can outsmart some of the potentially negative side effects, depicts the mental balance of that person. Being a most operative social networking website, Facebook attracts more of lonely people and hence provide them the safe platform to make themselves nonlonely. 


\section{REFERENCES}

Dykstra, P. A., van Tilburg, T., \& De Jong Gierveld, J. (2005). Changes in older adult loneliness: Results from a seven-year longitudinal study. Research on Aging, 27, 725-747.

Hawkley, L. C., \& Cacioppo, J. T. (2007). Aging and loneliness: Downhill quickly? Current Directions in Psychological Science, 16, 187-191.

Lauder, W., Mummery, K., Jones, M., \& Caperchione, C. (2006). A comparison of health behaviours in lonely and non-lonely populations. Psychology, Health, \& Medicine, 11, 233-245.

Medora, N., \& Woodward, J. C. (1986). Loneliness among adolescent college students at a Midwestern university. Adolescence, 21, 391-402.

Peplau, L.A., \& Perlman, D. (1982). Perspectives on loneliness. In L.A. Peplau \& D. Perlman (Eds.), Loneliness: A sourcebook of current theory, research and therapy (pp. 1-18). New York: Wiley.

Pinquart, M., \& Sörensen, S. (2003). Risk factor for loneliness in adulthood and old age - A meta-analysis. In S. P. Shohov (Ed.), Advances in Psychology Research, Vol. 19 (pp. 111-143). Hauppauge, NY: Nova Science Publishers.

Russell, D. W. (1996). UCLA Loneliness Scale (Version 3): Reliability, validity, and factor structure. Journal of Personality Assessment, 66, 20-40.

Schultz, N. R., \& Moore, D. (1988). Loneliness: Differences across three age levels. Journal of Social and Personal Relationships, 5, 275-284.

Schumaker, J. F., Shea, J. D., Monfries, M. M., \& Groth-Marnat, G. (1993). Loneliness and life satisfaction in Japan and Australia. Journal of Psychology, 127, 65-71.

Shaver, P., Furman, W., \& Buhrmester, D. (1985). Transition to college: Network changes, social skills, and loneliness. In S. Duck \& D. Perlman (Eds.), Understanding personal relationships: An interdisciplinary approach (pp. 193-219). Thousand Oaks, CA: Sage Publications.

Website: topexpensivelist.com, URL; http://topexpensivelist.com/main-10-countries-with-thehighest-number-of-facebook-users/2/.

Weiss, R. S. (1973). Loneliness: The experience of emotional and social isolation. Ambridge, MA: MIT Press.

Youngblade, L.M., Berlin, L.J. \& Beslky, J. (1999). Connections among loneliness, the ability to be alone, and peer relationships in young children. In K.J. Rotenberg \& S. Hymel (Eds.), Loneliness in childhood and adolescence (pp.135-152). New York: Cambridge University Press. 